\title{
YALTA KONFERANSI: SOĞUK SAVAŞA GIDEN YOL \\ YALTA CONFERENCE: THE ROAD TO COLD WAR
}

\author{
* Musa ÖZDEMIR \\ **Sadık ÇALIŞKAN \\ *** Fatih ÖZTÜRK
}

\section{Özet}

II. Dünya savaşı sırasında yapılan üç büyük konferanstan biri olan Yalta konferansı ABD, İngiltere ve Sovyetler Birliği arasında Avrupa'nın savaş sonrası yeniden yapılanmasını tartışmak amacı ile düzenlemiştir. Savaşın yıktığı ülkelerin yeniden tesisinin konuşulduğu konferansı takip eden bir kaç yıl içerisinde Doğu Avrupa ülkeleri Sovyetlerin etkisine girerek kıta ikiye bölünmüştür. İki kutuplu dünya düzeni ve soğuk savaşın temelleri Yalta konferansında alınan kararlarla atılmıştır. Yalta konferansı hem düzenlendiği zaman için hem de bugün için sonuçları ile tartışmalı bir konudur. Çalışmamızın amacı Avrupa'nın Doğu ve Batı bloğu olmak üzere ikiye ayrılmasına ve soğuk savaşa doğru giden süreçte Yalta konferansının etkilerini ve katkılarını değerlendirmektir.

Anahtar Kelimeler: Yalta Konferans1, Soğuk Savaş, II Dünya Savaşı

\begin{abstract}
Yalta Conference, which was the second of three wartime conferences among the Big three, The United States of America, The United Kingdom and The Soviet Union - was held for the purpose of discussing Europe's post - war reorganization. In a few years after the conference in which the re-establishment of nations of war-torn Europe was discussed, Eastern European countries came under the influence of Soviet Union and the continent was divided into two parts. Bipolar world order and the Cold War can be seen as results of the conference. The results of Yalta Conferencewere not only a matter of controversy for the time it was held, it is still a subject of controversy today. The aim of this paper is to evaluate the effects and contributions of Yalta Conference on the split of the Europe as the Eastern Bloc and the Western Bloc and on the move towards the Cold War.
\end{abstract}

Keywords: Yalta Conference, Cold War, World War II

\footnotetext{
* Okutman, İnönü Üniversitesi, Yabancı Diller Yüksekokulu **Okutman, İnönü Üniversitesi, Yabancı Diller Yüksekokulu ***Okutman, İnönü Üniversitesi, Yabancı Diller Yüksekokulu
} 
“Savaşı göze alan sadece askerini değil bütün milletini de feda etmeyi göze almak zorundadır. Savaşın makbulü, ĕger varsa, o da masa başında kazanilandır." Nizamü'l-mülk

\section{Giriş}

Büyük Selçuklu Devletinin en önemli vezirlerinden olan ve kaleme aldığı 'Siyasetname' adlı eseriyle çağlar sonrasına bile 1ş1k tutan büyük devlet ve siyaset adamı Nizâmülmülk'ün de dediği gibi savaşlarda her ne kadar kullanılan araçlar değişse de temel felsefe her zaman aynıdır: Düşmanı yenmek ve zafere ulaşmak için en az cephede verilen mücadele kadar o mücadeleyi sevk ve idare etme kabiliyeti de önemlidir. Bunun farkında olan Müttefik Devletler de (ABD, Sovyetler Birliği, İngiltere ve Fransa) İkinci Dünya Savaşı sırasında ve sonrasında gerçekleştirdikleri siyasal buluşma, toplantı ve konferanslarla savaşın yönünü ve seyrini tayin etmek istemişlerdir. Bu amaçla, ABD (Roosevelt), İngiltere (Churchill) ve Sovyetler Birliği (Stalin) liderleri başta olmak üzere diğer müttefik liderlerle irili ufaklı 30’u aşkın toplantı ve konferans yapılmıştır. Savaş öncesi ve sırasında müttefik kuvvetler arasında koordinasyon sağlamak için adeta mekik dokuyan İngiltere Başbakanı W. Churchill bu konferansların toplamda 16 tanesine; ABD Başkanı Roosevelt 12 ve Sovyet lider Stalin de 6'sına katılmıştır. Ancak, üç ülkenin de aynı anda katıldığı üç konferans yapılmıştır: Tahran Konferansı (28 Kasım-1 Aralık 1943), Yalta Konferansı (4-11 Şubat 1945) ve Potsdam Konferansı (17 Temmuz-2 Ağustos 1945).

\section{Amaç}

Bu makalenin amacı, savaşın müttefiklerin zaferiyle sonuçlanacağının nerdeyse aşikâr olduğu bir dönemde ve ağırlıklı olarak savaş sonrası oluşacak olan olası düzeni görüşmek ve karara bağlamak için yapılan Yalta (Şubat 1945)Konferansının dünyanın iki bloklu bir sisteme (Doğu - Batı Bloku) doğru evrilme sürecine olan etki ve katkısını değerlendirmek. 


\section{1. İkinci Dünya Savaşı Öncesi Durum}

Birinci Dünya Savaşı'nın sonunda imzalanan barış antlaşmaları sorunları çözmemiş ve yeni sorunları ortaya çıkarmıştır. Güçler dengesi yeniden biçimlenmişti. Dünya barışının korunması amacıyla, Milletler Cemiyeti kurulmuş, Avrupalı büyük ülkelerin de yer aldığı bazı Avrupalı devletler karşılıklı güvenliğin sağlanması için Locarno Antlaşması, A.B.D. ile Fransa Dışişleri Bakanlarının öncülüğünde de savaşı yasa dışı ilan eden Briand-Kelogg Paktı imzalanarak yürürlüğe sokulmuştu. Ancak, barışın korunmasına yönelik bu çabalar yeterli olmamıştır.

İtalya'da faşist rejiminin kurulması ve bu rejimin yayılmacılığa yönelmesi, Almanya'da Hitler önderliğindeki Nasyonal Sosyalist İşçi Partisi'nin (NAZI) tüm demokratik olanakları kullanarak 1933 yılında iktidara tırmanarak Versailles Barış Antlaşması düzenini ortadan kaldırmaya çalışması ve Büyük Germen İmparatorluğunu kurmak istemesi, Japonya'nın da Uzakdoğu'da güçler dengesini alt-üst ederek militarist temellere dayalı bir imparatorluk kurma tutumuna girmesi, İkinci Dünya Savaşı'nın çıkmasına yol açan en önemli gelişmeler olmuştur.

Versailles Antlaşmasının silahsızlandırma ve savaş tazminatı gibi ağır maddelerini kabullenmeyen Almanya ve Birinci Dünya Savaşında kazanan devletler safında olmasına rağmen İngiltere ve Fransa tarafindan kandırıldığını düşünen İtalya ile öteden beri Uzakdoğu'nun tek hâkimi olmayı arzulayan Japonya'nın katılımı ile öncelikli olarak Sovyetlere karşı 1936'da Anti Komintern Paktı'nın kurulması, İkinci Dünya Savaşı'na giden süreçte önemli bir dönüm noktası olmuştur. İtalya'nın da bir yıl sonra bu Pakta katılmasıyla "Berlin-Roma-Tokyo Mihveri" oluşmuş ve dünya yaklaşık 20 yıl sonra yeniden büyük bir savaşın eşiğine gelmiştir.

'Tek ulus, tek devlet' (einVolk, einReich) fikrini kendisine politik bir hedef olarak belirleyen ve Birinci Dünya Savaşı sonrası parçalanan Alman birliğini yeniden tesis edip tüm Almanları tek devlet altında birleştirmek isteyen Hitler, bu amacını gerçekleştirmek için ilk olarak Mart 1938'te Avusturya'yı ilhak etti. İngiltere ve Fransa'nın bu duruma yeterince ses çıkarmamasından cesaret alan Hitler yönetimindeki Almanya, 3.5 milyon Alman'ın yaşadığı Çekoslovakya'nın Südetler bölgesini de bu yolla kendi topraklarına katmak için harekete geçti. Daha önce 
Çekoslovakya ile bir ittifak anlaşması yapan Fransa, bu anlaşmanın hükümlerine sadık kalmayarak bu konuda İngiltere ile hareket edeceğini belirtmiştir. Sovyetler Birliği'nin bu ülkeye yapılacak olası bir saldırıda Çekoslovakya'ya yardım edeceğini bildirmesi ve Almanya'nın sınıra askeri yı̆̆ınak yapmaya başlaması, Avrupa'da yeni bir gerginliğin çıkmasına yol açtı. Bu gerginliği yatıştırmak ve Avrupa'da yeni bir savaşın çıkmasını önlemek için harekete geçen İngiltere Başbakanı Chamberlain Münih'te Hitler'le iki kez görüşmüştür. Bu görüşmelerde, Hitler geri adım atmayacağını Chamberalin'e bildirmiş; Chamberlain ise Avrupa'da barışın devamı için birkaç küçük devletin feda edilebileceği izlenimi(aslında yanılgl) edinmiştir. Durumu daha ayrıntılı ele almak için İngiltere, Fransa, İtalya ve Almanya’nın liderlerinin katılımıyla 29 Eylül 1938'de Münih Konferansı düzenlenmiştir. Bu konferansın sonucunda Almanya istediğini elde etmiş ve Südetler Bölgesini hiçbir zorlukla karşılaşmadan ele geçirmiştir.

Tarihe 'Münih Düzenlemesi' olarak geçen bu toplantının sonunda alınan kararlar, Çekoslovakya gibi küçük bir devletin feda edilmesine ve daha sonra soğuk savaş yıllarında Sovyetlere yaklaşmasına yol açmakla kalmamış aynı zamanda ikinci bir büyük savaşı ekonomik ve askeri olarak göze alamayacak kadar zayıf düşmüş olan İngiltere ve Fransa'nın uyguladıkları Hitleri yatıştırma politikasının kaçınılmaz bir sonucu olarak Almanya'yı emellerine ulaşmada daha da motive etmiştir.

Tüm politikasını 'bir ulus, bir devlet' (einVolk, einReich) ve 'hayat sahası' (Lebensraum)gibi yayılmacı ilkeler üzerine inşa eden ve bu politikasını da Avusturya'yı ve Çekoslovakya'nın Südetler Bölgesini ilhak ederek bir ölçüde hayata geçiren Hitler önderliğindeki Almanya, Avrupa'nın iki büyük devleti İngiltere ve Fransa'nın görece sessizliğini ve duyarsızlığından aldığı cesaretle 1 Eylül 1939'da Polonya'ya saldırarak İkinci Dünya Savaşı’nı fiilen başlatmıştır. Almanya açısından Polonya'ya savaş açılmasının birincil nedeni bu ülke sınırları içinde yer alan ve Alman nüfusun ağırlıklı olarak yaşadığg Danzing serbest şehri üzerindeki ihtilaflardır. Birinci Dünya Savaşı sona erdiğinde bu bölge yapılan anlaşmalarla Milletler Cemiyeti garantisi altına sokulmuştu. Almanya ise Wilson'un ilkelerinden self-determinasyon (halkların kendi geleceğine kendi karar vermesi ilkesi) ilkesi gereği bu bölge üzerinde hak iddia etmekteydi ancak Polonya Almanya'nın bu talebini ilk başta reddetmiş ve 
daha sonra Danzing şehrinin sadece Almanya - Polonya ortak garantisi altına almayı kabul edebileceğini Hitler'e bildirmiştir. $\mathrm{Bu}$ durum üzerine, Polonya artık Almanya'nın olası bir müttefiki değil açık bir hedefi haline gelmiştir ${ }^{1}$.

\section{Savaşın Başlaması Ve Yayılması}

Alman birliklerinin Polonya'yı işgal etmeye başlaması İngiltere ve Fransa'yı panikletmiş ve işgalden iki gün sonra bu iki başat ülke Almanya'ya savaş ilan etmek durumunda kalmışlardır. Birinci Dünya Savaşından zaferle çıkan Avrupa'nın bu iki büyük devleti aslında yeni bir savaşı kaldıramayacaklarının farkındaydılar; bu nedenle Çekoslovakya'nın parçalanmasına ses çıkarmamışlardı. Polonya'nın da Alman isteklerine direnmemesini bekliyorlardı; fakat Çekoslovakya olayında azalan prestijlerini tümden bitirmemek adına bu konuda Polonya'ya baskı yapmadılar².

Avrupa'da tüm bunlar yaşanırken diğer yandan Sovyetler Birliği, Baltık ülkelerini ele geçirmeye başlamış ve Finlandiya’ya kadar ilerlemiştir. Finliler diğer Baltık ülkeleri gibi kolayca teslim olmayıp uzun süre Sovyet işgaline karşı direnmişlerse de sonunda işgale boyun eğmek zorunda kalmışlardı. Almanya ise, Norveç ve Danimarka'yı işgal ettikten sonra, Avrupa içlerinde ilerleyerek Hollanda, Belçika ve Fransa'yı da işgal ederek, bu ülkeleri kendi topraklarına katmıştır. Bununla birlikte, Almanya ve İtalya, büyük oranda İngiliz idaresinde olan Kuzey Afrika'da da yayılmaya çalışmışlardır. Japonya'nın da, Aralık 1941'de Pearl Harbour baskınıyla Amerikan donanmasına ve hava gücüne büyük ölçüde zayiat verdirerek ABD'yi de savaşa sürüklemesi sonucu, savaş tüm dünyaya yayılmıştır.

Ancak, savaşın ilk zamanlarında Avrupa'nın Balkanlar dâhil neredeyse tamamını ele geçiren Mihver Devletleri'nin ilerleyişii, Almanya'nın 1941 yılının Haziran ayında daha önce Saldırmazlık Paktı imzaladığı Sovyetler Birliğine savaş ilan etmesiyle hız kaybetmiştir. İlk aşamada Alman birlikleri Moskova’ya kadar ilerlese de coğrafi ve iklimsel şartlardan dolayı Sovyetler Alman ilerleyişini Stalingrad'da durdurmuş ve sonrasında geri çekilmeye zorlamıştır. Savaşın seyri Stalingrad'da Mihver ittifakı

\footnotetext{
${ }^{1}$ Yakut,K. \& Yakut, E. (2013). Siyasi Tarih-II. Eskişehir: Anadolu Üniversitesi Yayınları.

${ }^{2}$ Sander, O. (1989). Siyasi Tarih. Ankara: İmge Kitabevi Yayınları.
} 
aleyhine değişmeye başlamış ve ABD'nin de Uzakdoğu'da Japonya'nın tahrikleriyle savaşa dâhil olması savaşın tüm seyrini değiştirmiştir.

Mihver Devletleri'nin (Almanya-İtalya-Japonya) yayılmacılığına karşı ABD, İngiltere ve Sovyetler Birliği ittifak yapmışlardı. Savaş sırasında ABD yönetiminin İngiltere ve Sovyetler Birliği başta olmak üzere müttefik devletlere yaptığı büyük ekonomik yardımlar sayesinde cephelerde Mihver Devletlerine karşı üstünlük sağlanabilmiş ve Mihver Devletlerinin tüm cephelerde teslim olmasıyla, dünyaya beş buçuk yıl felaket yaşatan İkinci Dünya Savaşı sona ermiştir.

\section{Savaşın Sonu Ve Diplomasinin Gücü}

Tarihin tanıklık ettiği en büyük kanlı savaşın sadece cephelerde kazanılan zaferlerle bir sonuca ulaşamayacağı aşikârdı ve bu durum müttefik liderleri diplomasinin gücünden azami ölçüde faydalanmaya itiyordu. $\mathrm{Bu}$ amaçla, müttefik liderler, Avrupa'da savaşın bittiği Mayıs 1945'e kadar irili ufaklı çok sayıda diplomatik konferans ya da toplantı düzenleyerek hem savaşın seyrine yön vermek hem de savaş sonrası oluşacak yenidünya düzenini bir anlamda şekillendirmek istiyorlardı. Tüm bu diplomatik görüşmeler içerisinde belki de en önemlisi olan savaş sonrası oluşan güçler dengesi ve çift kutuplu dünya düzeninin bir anlamda temellerinin atıldığ Y Yalta Konferansidir.

İkinci Dünya Savaşı devam ederken savaşın gidişatına göre farklı merkezlerde bir araya gelerek Avrupa'nın savaştaki durumu ve geleceğiyle ilgili kararları alan o dönemin askeri, siyasi ve ekonomik olarak büyük güçleri olan ABD, Sovyetler Birliği ve İngiltere'ydi. Ancak, ABD'nin ekonomik, Sovyetler Birliği'nin ise askeri gücüne sahip olmayan İngiltere'nin zayıflığı ve yıpranmışlığı savaş sonrasında açıkça ortaya çıkmış ve böylece iki büyük devlet olan ABD ve SSCB Avrupa'ya biçim vermişlerdir. Nitekim, savaş sonrası Avrupa'da öngörülen toplumsal ve siyasal yapı da büyük ölçüde bu iki ülke tarafından belirlenmiştir. Bu durum, savaşın bitimiyle özelde Avrupa'da ve genelde tüm dünyada meydana gelen gelişmelerin anlaşılmasına 1 şı tutacak çok önemli bir noktadır ${ }^{3}$.

\footnotetext{
${ }^{3}$ ctdt.blogcu.com,(2017). Soğuk Savaşa Geçiş Dönemi 1945-1947. http://ctdt.blogcu.com/soguk-
} savasa-gecis-donemi-1945-1947/4294208. Erişim Tarihi: 30.05.2017 


\section{Yalta Konferansı Öncesi Durum}

İkinci Dünya Savaşı, dünya güç dengesini tamamen değiştirdi. Bir zamanların güçlü Avrupa'sı artık yoktu. Avrupa bir anlamda diz çökmüştü; Fabrika ve ulaşım bağlantıları yok edilmiş, geleneksel ticaret bağlantıları kesilmiş ve hammadde ve gıda stokundaki sıkıntılar had safhaya ulaşmıştı. Avrupa artık dünyaya nizam veren bir güç merkezi olmaktan çok uzaktı. Savaştan daha güçlü çıkan iki çevre ülke, ABD ve SSCB, ise yeni güç merkezleri olarak ortaya çıkmıştı.

SSCB savaştan topraklarını genişleterek ve Hitler'in Almanya'sına karşı en büyük savaşı vermekten dolayı prestijli bir hava ile çıkmıştı. Özellikle Almanlara karşı kahramanca bir direnişin gösterildiği Stalingrad zaferiyle beraber adeta yeniden doğmuştu. Ayrıca, savaşın belki de en çok insan kaybı veren ülkesi olmasına rağmen, Sovyet Kızıl Ordusu, ABD ordusunun tersine, savaşın sonunda terhis edilmemişti. Bundan dolayı, Sovyetler Birliği, askeri insan gücü ve ağır silahlar açısından gerçek bir sayısal üstünlüğe sahipti ${ }^{4}$.

İkinci Dünya Savaşı'nın en büyük galibi olarak ortaya çıkan Amerika Birleşik Devletleri'nin ise insani ve maddi kayıpları nispeten düşüktü ve savaşın sonunda ordusu neredeyse tamamen terhis edilmiş olmasına rağmen dünyanın en önde gelen askeri gücü haline gelmişti. Donanması ve hava kuvvetleri rakipsiz olan $\mathrm{ABD}$, aynı zamanda, 1949 yılına kadar nükleer silah üretme kapasitesine sahip tek ülkeydi. Bunun yanı sıra, savaş Amerika'yı diğer ülkeler kadar ekonomik olarak sarsmamış, bilakis hem ticari hacim hem de sanayi ve tarımsal üretim bakımından dünyanın önde gelen ekonomik gücü olma konumunu daha da pekiştirmişti. ABD artık dünyanın altın rezervlerinin üçte ikisinden fazlasına sahipti ve ‘dolar' birincil uluslararası para birimi haline geliyordu.

\section{Yalta Konferansı}

İkinci Dünya Savaşı sırasında, 'Büyük Üçlü’ denilen Birleşik Devletler, Birleşik Krallık ve Sovyetler Birliği savaş sonrası askeri, siyasi ve ekonomik gelişmelerle ilgili

\footnotetext{
${ }^{4}$ www.cvce.eu,(2017).TheColdWar 1945-1989.www.cvce.eu/obj/the_cold_war_1945_1989_full_texten-6dfe06ed-4790-48a4-8968-855e90593185.html.Erişim Tarihi: 29.05.2017
} 
birbirleriyle ve daha az güçlü devletlerle çeşitli anlaşmalar imzalamışlardı. Bunlar arasında en tartışmalı olanı ve günümüzde dahi birçok tarihçi tarafından 'Yalta Düzeni' olarak adlandırılan bugünkü dünya sisteminin temellerinin atıldığı Yalta Konferansı'nda imzalanan anlaşmalard1. Yalta Konferansı, müttefikler arası güvensizlik tohumlarının atıldığı ve Soğuk Savaş döneminin ilk kıvılcımlarının ateşlendiği zirve olması münasebetiyle bu çalışmanın da temelini teşkil etmektedir.

4-11 Şubat 1945'te Ukrayna'nın güney kıyısında yer alan liman kenti Yalta'da düzenlenen konferansa savaşın sonunda güçlerini muhafaza eden hatta arttıran ve tarihte "Büyük Üçlü" olarak anılan ABD Başkanı Franklin Delano Roosevelt, Sovyet lider Joseph Stalin ve İngiltere Başbakanı Winston Churchill katıldı. Tarihe 'Kırım Konferansı' olarak da geçen ve yedi gün boyunca süren ve bir kısmı 'Argonaut' koduyla gizli olarak gerçekleştirilen bu toplantılarda genel olarak Almanya'nın teslim alınarak silahsızlandırılması ve bölünmesi için bir strateji oluşturmak, Birleşmiş Milletler'in kurulması, Özgür Avrupa Bildirgesi'nin imzalanarak savaşta büyük bir yıkıma uğrayan ve ezilen Doğu Avrupa ülkelerinde serbest seçimler yoluyla demokratik ve uygar bir gelecek inşa edilmesi, Sovyetler ile Polonya arasındaki sınırın net olarak belirlenmesi ve Pasifikte ABD tarafından Japonya'ya karşı sürdürülen savaşın ivedi bir zaferle sonuçlandırılması gibi meseleler tartışıldı ${ }^{5}$. Genel olarak Yalta'da gündeme getirilen ve üzerinde anlaşma sağlanan konular şunlardı:

- Öncelikle Nazi Almanya’sının ‘şartsız teslim’ olması konusunda Büyük Üçlü anlaşmıştı. Savaşın ardından ülke, Fransa'nın da dahil olacağı şekilde dört ülke tarafından işgal edilecek ve Berlin de yine aynı ülkeler tarafından paylaştırılacaktı. Sovyetler Birliği Almanya'nın doğu bölgesini, İngiltere kuzeybatısını ve ABD güneybatı bölgesini işgal edeceklerdi. Sovyet işgal bölgesi içinde kalan Berlin de aynı biçimde işgal bölgelerine ayrılacaklardı. Ancak Batılıların Berlin'e nasıl geçecekleri Yalta'da belirlenmedi. Bu konu Müttefikler arasında ilişkiler bozulunca büyük sorun çıkaracak, Batılılar ile Sovyetler Birliğini bir çatışmanın eşiğine kadar getirecekti.

${ }^{5}$ Engbith, L. (2011).True Diplomacy At Yalta. http://www.ctn.state.ct.us/press_room/osh/NHDYalta.pdf. Erişim tarihi: 25.04.2017 
Daha sonra, Berlin Ablukası esnasında da açık bir biçimde ortaya çıkmıştır ki aslında ABD, İngiltere ve Fransa blok halinde hareket ederek ortak kararlar almakta ve Sovyetler tek başına bir blok oluşturmaktaydı. Yani, Soğuk Savaşın Doğu ve Batı blokları Yalta'dan itibaren belirmeye başlamıştı.

- Stalin, İngiliz ve Amerikan işgal bölgelerinden verilmek şartıyla Fransa'nın da Almanya'da dördüncü işgal kuvveti olmasını kabul etti. Fransa'ya Müttefikler Kontrol Konseyi'nde bir sandalye de verilecekti.

- Alman ordusu Nazi etkisinden arındırılıp silahsızlandırılacaktı.

- Merkezi Moskova'da olan bir savaş tamirat ve tazminat komisyonu kurulacaktı. Aslında ABD ve İngiltere bu konuda çok katı istekli değillerdi; onlara göre Almanya Birinci Dünya Savaşı sonrası gibi yine ağır bir savaş tazminatı altına sokulursa Avrupa'da yeni bir savaşın çıkmaması garanti edilemezdi. Sovyetler ise Almanların tüm savaş endüstrisine ek olarak kendisine savaş tazminatı ödenmesinde diretiyordu. Hatta, bu konuda İkinci Dünya Savaşı öncesi Fransa'nın Almanya'ya karşı uyguladığı politikadan daha sert ve ağır yaptırımlar içeren bir tutum öngörüyordu.

- Konferansta tartışılan Polonya'nın durumu, o ana kadar Kızıl Ordu (Sovyet Ordusu) tarafından işgal altında olduğu için karmaşıktı. Kızıl Ordu tarafından kurulan Hazırlayıc1 Polonya Hükümeti, Polonya Birliğinin Geçici Hükümeti olarak demokratik seçimler yapılana kadar ülkeyi yönetmesine karar verildi. Aslında, Sovyetlerin kuklası olan bu hükümet, Londra'da kurulan ve Avrupa değerlerine dayalı, serbest seçimlerde 1srar eden daha demokratik bir tutum izleyen sürgündeki Polonya hükümetini net bir şekilde dışlıyordu.

- Stalin'e göre, Polonya'nın doğu sınırı (Sovyet sınırı) Curzon Hattı'nı esas almalı ve Polonya, doğuda kaybedeceği bu toprakları batıda Almanya'dan alacağı topraklarla tazmin etmeliydi. 
- Sovyetler Birliği ve Yugoslavya vatandaşları, onaylarının alınmasına gerek görülmeksizin kendi ülkelerine teslim edilecekti ${ }^{6}$.

Yalta Konferansına her üç devlet de kendilerine ait farklı gündemlerle gelmişlerdi. İngilizler, imparatorluklarını korumak isterken; Sovyetler, daha fazla toprak edinmek ve işgal ettiği yerlerde gücünü ve nüfuzunu arttırmak istiyordu. Savaşın bitimine doğru askeri anlamda Avrupa'nın en güçlüsü olarak konferansa katılan Sovyetler Birliği, Romanya, Bulgaristan ve Polonya'nın büyük bir bölümü ve Macaristan, Yugoslavya ve Çekoslovakya'yı kontrol altına almış ve Berlin'den de sadece 100 mil uzaktaydı. $\mathrm{Bu}$, Yalta'da Sovyetlerin elini güçlendiren bir durum teşkil ediyordu. Amerikalıların gündemi ise Pasifikte Japonlara karşı yürüttükleri savaşta Sovyetlerin desteğini almak ve savaş sonrası çözümleri ve oluşacak yeni düzeni tartışmaktı. Ayrıca, Roosevelt, Stalin'den Birleşmiş Milletler'e katılmak için bir taahhütte bulunmasını da umuyordu. Sovyetler ilk olarak Polonya konusunu gündeme getirdi ve Stalin, bu konudaki kararlığını şu sözlerle dile getirdi:

"Rusya halkı için Polonya sorunu sadece bir şeref meselesi değil aynı zamanda bir güvenlik meselesidir.Tarihi boyunca Polonya, düşmanın geçtiği koridor olmuştu; Polonya, Rusya için bir ölüm kalım meselesidir."

Bu sözlerden de anlaşılacağı gibi Stalin, Polonya ile ilgili taleplerinden bazılarının pazarlık konusu dahi olmadığını belirterek Polonya'nın doğu kesiminin bir kısmını almayı ve Polonya'nın da milyonlarca Alman'1 zorlayarak Batı sinırlarını genişletmesiyle bu durumu telafi etmesini öneriyordu. Ayrıca isteksizce de olsa özellikle Churchill'in diretmesiyle Stalin, yakın bir tarihte kurulan Komünist kukla hükümetine rağmen Polonya'da serbest seçimler yapılması sözü de verdi. Ancak, Stalin'in özgür seçim sözünü tutmaya hiç de niyetli olmadığı çok geçmeden belli olacaktı çünkü Polonya'da ilk serbest seçimler Yalta Konferansı'ndan yaklaşık elli yıl sonra yapılabilmiştir ${ }^{8}$. Stalin'in özgür seçimlere izin vereceğine dair sözlerini yerine

\footnotetext{
${ }^{6}$ Forrest C. Pogue, C. F. (1956). TheMeaning of Yalta: Big Three Diplomacyand New Balance of Power. Louisiana: Louisiana StateUniversityPress. ${ }^{7}$ www.thelatinlibrary.com, (2017).The Yalta Conference, 1945.http://www.thelatinlibrary.com/imperialism/notes/yalta.html. Erişim Tarihi: 02.06.2017 ${ }^{8}$ www.thelatinlibrary.com,(2017). The Yalta Conference, 1945.

http://www.thelatinlibrary.com/imperialism/notes/yalta.html. Erişim Tarihi: 02.06.2017
} 
getirmeyeceği anlaş1ldıktan sonra, Roosevelt ve Churchill kendi ülkelerinde Doğu Avrupa'yı Sovyetlere 'satmakla' eleştirildiler. Ancak, Doğu Avrupa Kızıl Ordunun işgali altında olduğundan ve Uzakdoğu'da savaş hala devam ettiğinden dolayı ABD ve İngiltere'nin eli Sovyetlere karşı müzakere masasında görece daha zayıftı. Nitekim, Roosevelt de daha sonra konferansa dair bir değerlendirmesinde bu durumu "Sonuçtan memnun olduğumu söyleyemem. Ancak, yapabileceğim en iyi şey de buydu." diyerek bir anlamda itiraf etmiştir.

Müttefikler, Avrupa'daki zaferin neredeyse kaçınılmaz olduğunu, ancak Japonya'ya karşı verilen Pasifik savaşının biraz daha süreceğini bilerek Yalta'ya gelmişlerdi. Birleşik Devletler ise Japonya ile hâlâ savaş halindeydi ve görünürde kesin bir zafer henüz yoktu. Bu nedenle Pasifik’teki savaşın uzun sürmesini istemeyen ve Sovyetlerin Pasifik’te kuzeyden cephe açmasını zafer için önemli bir stratejik avantaj olarak gören Birleşik Devletler ve İngiltere, Sovyetler Birliği'nden Japonya'ya karşı savaş ilan etmesini istedi. Stalin ise, Sakalin Adası'nın güney yarısını, Kuril Adalarını ve Mançurya'daki Dairen ve Port Arthur Limanları'nı kontrol altında tutmak karşılığında, Almanya'nın teslim edilmesinden üç ay sonra Japonya'ya savaş açmayı kabul etti. Doğrusu bu anlaşma, Yalta Konferansı'nın en önemli somut başarısı olarak kayıtlara geçmiştir?.

Aslında Roosevelt'in, Stalin'i bu konuda ikna etmeye çalışarak zamanını boşa harcamasına gerek yoktu; zira Sovyetler zaten daha önce Rus-Japon Savaşı sırasında Mançurya'da ayrıcalıkların yitirilmesinden kaynaklanan aşağılanma duygularını hafifletmek istiyorlardı. Japonlara kaybettikleri toprakları daha fazlasıyla geri almak için bu kaçırılmayacak bir firsattı. Ancak, Stalin'in 'poker yüz' olarak tabir edilen duygularını muhatabına belli etmeyen bir yüz ifadesine sahip olduğundan habersiz olan Roosevelt esas amacına ulaşmış olmanın verdiği rahatlık ve coşkuyla evine dönecekti ${ }^{10}$. Konferansta tartışılan önemli başlıklardan biri de yeni bir dünya barışı koruma örgütü olan Birleşmiş Milletler'in kurulması gerektiğiydi. Birinci Dünya

${ }^{9}$ history.state.gov,(2017).The Yalta Conference, 1945. https://history.state.gov/milestones/19371945/yalta-conf. Erişim Tarihi: 01.06.2017

${ }^{10}$ www.thelatinlibrary.com, (2017). The Yalta Conference, 1945.

http://www.thelatinlibrary.com/imperialism/notes/yalta.html. Erişim Tarihi: 02.06.2017 
Savaşından hemen sonra kurulan Milletler Cemiyeti'nin yeni bir savaşı önlemedeki etkisizliği ve başarısızlığının bir sonucu olarak ortaya çıkan yeni bir barış örgütü kurma ihtiyacı ABD Başkanı Roosevelt'in öncelikleri arasındaydı. Birinci Dünya Savaşından sonra yine bir ABD Başkanı olan W. Wilson'un girişimleriyle oluşturulan Milletler Cemiyeti örgütüne benzer fakat bu defa daha etkin olması öngörülen yeni organizasyonun önderliğini Birleşik Devletler, Sovyetler Birliği ve İngiltere yapacaktı. Sovyetler Birliği, kendisine fiilen bağlı ya da etkisi ve nüfuzu altındaki her bir Sovyet Cumhuriyeti için bir tane olmak üzere, yeni kurulacak örgütte on altı oy hakkı istedi, fakat yapılan uzun müzakerelerin sonucunda Sovyetlere üç oy hakkı verilmesi konusunda mutabakata varıldı. Konferansta ayrıca 25 Nisan 1945'te San Francisco'da Birleşmiş Milletlerin kurulması için planlar tamamlanmasıyla ilgili yapılması öngörülen yeni zirveye Fransa ve Çin'in de katılmaları için çağrıda bulunulması kararlaştırıld $1^{11}$.

Yalta Konferansı, görünürde başarılı bir şekilde gerçekleşmiş olsa da, perde arkasında, savaş tazminatları ve Polonya ile ilgili konularda, özellikle Churchill ile Stalin arasında giderek artan bir gerginlik hissediliyordu. Hatta, konferanstan sonra Churchill'in Roosevelt'e "Sovyetler Birliği, özgür dünya için bir tehdit haline gelmeye başladı." diye yazdığı bilinmektedir $^{12}$.

Konferans, 11 Şubat'ta karşılıklı dostluk ve iyi niyet mesajlarıyla sona erdi. Akşam saatlerinde verilen son yemekte Churchill, 'Savaşın ateşi, ülkeler arasındaki geçmişten kaynaklanan yanlış anlaşılmaları yakmıştır.' diyerek Stalin'e hitaben umut verici bir konuşma yapmıştır. Ancak, toplantıda alınan kararların yazımı sırasında, Yalta'nın kendisi için gerçek anlamını şu şekilde özetlemiştir: “Artık her şey yürütüldüğü dönemin ruhuna uygun şekilde sona ermiştir"13.

\footnotetext{
${ }^{11}$ Scott, N. (2017). TheConferences At Yalta andPotsdam. http://www2.needham.k12.ma.us/nhs/cur/Baker_00/2002-p3/baker_p3_12-01_sn/. Erişim Tarihi: 31.05.2017

${ }^{12}$ Clare, J. D. (2017).Personalities At TheConferences. http://www.johndclare.net/cold_war4_personalities.htm. Erişim Tarihi: 30.05.2017

${ }^{13}$ Forrest C. Pogue, C. F. (1956). TheMeaning of Yalta: Big Three Diplomacyand New Balance of Power. Louisiana: Louisiana StateUniversityPress.
} 


\section{Sonuç Ve Değerlendirme: Yalta Ve Soğuk Savaş İlişkisi}

1940'ların sonunda başlayan ve 1989'da sona eren Soğuk Savaş, 20. yüzyılın en tartışmalı olaylarından biridir. Bugün bile, bu savaş ve nedenleri ile ilgili yeni bilgiler ortaya çıkıyor. 'Soğuk Savaş' terimi, ABD ve SSCB'nin hiçbir zaman bir cephe savaşındaki gibi karşı karşıya gelmediği fakat iki süper güç olarak etki ettikleri devletler veya bölgeler üzerinden yürüttükleri bir güç gösterisi olarak adlandırılabilir. ABD ve SSCB'nin ekonomik ve politik ideolojileri üzerinden çatıştığı bu dönemde, kapitalist, demokratik bir ulus olan $\mathrm{ABD}$, serbest seçimler ve serbest pazarlar geliştirmeye çalışırken; komünist, totaliter bir devlet olan SSCB ise sınırlarının güvenliğini ve Komünist partinin siyasi egemenliğini sağlamaya çalışıyordu.

Tarihçilerin üzerinde fikir birliğine varamadıkları bir diğer nokta da bu savaşın kaynağına dairdir. Soğuk Savaşın sebebi olarak görülen çeşitli faktörler vardır ve tarihçiler arasından Soğuk Savaşı tetiklediğine dair tartışmaları başlatan olaylardan biri de Büyük Üçlü'nün siyasal ideolojileri arasındaki çatışmaların gün yüzüne çıkmaya başladığı Yalta Konferansıdır. Stalin, Doğu Avrupa ve Almanya'da komünizmin yayılmasını arzularken; Churchill ve Roosevelt ise demokratik seçimlerin yapıldığı ve serbest ticarete dayalı bir liberalizmin bölgede egemen olmasını istiyordu. Bu bakımdan, Yalta, işbirliği ve anlaşmayı temel alarak dünyada yeni bir düzen kurmaya yönelik son teşebbüslerden biri gibi görünüyordu. Doğrusu, dünya henüz iki güç yarımküresine ayrılmamıştı, ancak Batılı Devletler, Stalin'in Sovyet tankları tarafından kurtarılmış topraklardaki rolünü kabul etmek zorundaydılar. Orta ve Doğu Avrupa, bundan böyle Kızıl Ordu'nun münhasır kontrolünde idi. Aslında, bir anlamda, Stalin 1944'te Churchill ile yaptıkları 'Yüzdeler Antlaşmasına' uygun davraniyordu.

Churchill ve Stalin arasında 1944 Ekim'inde gerçeklesen ve amacı Doğu Avrupa'da etki alanlarının kesin olarak tespit edilmesi olan ve tarihe 'Yüzdeler Anlaşması' diye geçen bu antlaşmada, İngiltere ve SSCB Doğu Avrupa'da savaş sonrası sahip olacakları nüfuz ve etki üstünlüğünü 'yüzdelik ifadelerle' belirlemişlerdir. Macaristan'da İngiltere \%50, Sovyetler \%50; Bulgaristan'da \%25, \%75; Romanya $\% 10, \% 90$; Yugoslavya'da \%50, \%50; Yunanistan'da \%90, \%10 gibi yüzdeliklerle 
belirtilen düzenlemeler vard1. Churchill'e göre, bu anlaşma o andaki savaş durumu ile ilgili bir düzenlemeydi ve savaş sonunda imzalanacak olan barış antlaşmalarında değişikliklere açıktı. Her ne olursa olsun, böyle bir düzenlemenin savaş sonrası gelişmelerini etkileyeceği aşikârdı ve öyle de oldu. Sovyetler Birliği, Doğu Avrupa ülkelerindeki askeri üstünlüğünü sonuna kadar kullanırken, Yunanistan'a karışmadı ve İngiltere, Yunan iç savaşında kralcı hükümete tam destek verirken, Yunan komünistlerine doğrudan yardım yapmad $1^{14}$.

Konferansa katılan üç liderin kişilik özellikleri ve Konferans esnasındaki etkilerine bakılacak olursa; Stalin'in güçlü konumda olan liderdi çünkü orduları yalnızca Berlin'e doğru ilerlemekle kalmamış, aynı zamanda Roosevelt ve Churchill'e sağlık sorunlarından dolayı doktorunun kendisine seyahat etmeyi yasakladığını söyleyerek konferansın SSCB sınırları içinde yapılmasını sağlamıştır. Ayrıca, Stalin müttefikleri hakkında önemli bilgilere sahipti. İngiltere'de daha sonra 'Cambridge Beşlisi' olarak bilinen bir grup casus, kendisine gerekli tüm İngiliz Dışişleri Bakanlığı'na ait belgelerini temin etmişti. ABD Dışişleri Bakanlığı için çalışan bir Sovyet casusu olan Alger Hiss de Amerikan delegasyonunun içine sızmayı başarmıştı ${ }^{15}$.

Roosevelt, konferanstaki en zayıf lider konumundaydı çünkü hem sağlık sorunlarında dolayı iyi görünmüyordu- ki zaten konferanstan yaklaşık iki ay sonra 12 Nisan'da beyin kanamasından vefat etmiştir -hem de en önemlisi, kendisinin Stalin'le özel bir dostluğa sahip olduğuna ve bu dostluğun Stalin'in kötü niyetli davranmasını engelleyeceğine inanıyordu. Nitekim konferanstan önce verdiği bir demeçte, Stalin'in ülkesinin güvenliği dışında bir şey istemediğine dair bir hissiyatı olduğunu ve eğer kendisiyle işbirliğine devam edilirse Stalin'in de demokratik ve barışçıl bir dünya için çalışacağına inandığını dile getirmiştir.

Yalta, savaş sonundan ve yurtdışındaki Roosevelt'in son gezisinden önceki son büyük toplantıyd1. Gözlemcilere göre Roosevelt zaten hasta ve bitkin görünüyordu. Muhtemelen en önemli amacı, Sovyetler Birliği'nin Birleşmiş Milletler'e katılımını

\footnotetext{
${ }^{14}$ ctdt.blogcu.com,(2017). Soğuk Savaşa Geçiş Dönemi 1945-1947. http://ctdt.blogcu.com/soguksavasa-gecis-donemi-1945-1947/4294208. Erişim Tarihi: 30.05.2017

${ }^{15}$ Clare, J. D. (2017).Personalities At TheConferences.

http://www.johndclare.net/cold_war4_personalities.htm. Erişim Tarihi: 30.05.2017
} 
sağlamaktı ama bu da Güvenlik Konseyinin her daimi üyesine veto yetkisi vererek BM'yi önemli ölçüde zayıflatan bir durumdu. Amaçlarından bir diğeri ise, atom bombasının etkinliği henüz kanıtlanmadığı için, Sovyetler Birliği'ni Japonya'ya karşı savaşa sokmaktı. Sovyet Kızıl Ordusu, zaten Nazi kuvvetlerini Doğu Avrupa'nın birçok yerinden süpürmüştü; bu yüzden, Stalin zaten Avrupa ile Sovyetler arasında etki alanı olarak kurmayı planladığı bir tampon bölge oluşturmuş gibiydi.

Yalta Konferansı, Büyük Üçlü arasında savaş sırasında kurulan fikir ve hedef birliğinin bozulmasına yönelik işaretler vermesi açısından önem taşımaktadır. Mesela, Churchill, konferansta alınan kararlarda Sovyetlere çok fazla taviz verildiğini itiraf etmişti. Churchill, Stalin'in Doğu Avrupa'da bir Sovyet imparatorluğu kurmayı tasarladığı konusunda giderek endişeleniyordu. Stalin'in tüm Doğu Avrupa'yı ele geçirmesinin engellenmesi gerektiğine inanıyordu. Hatta, konferanstan sonra bir konuşmasında; "Zavallı Neville Chamberlain, Hitler'e güvenebileceğine inanıyordu. Yanılıyordu. Fakat ben Stalin hakkında yanıldığımı sanmıyorum"16. Bu yüzden, konferansta Churchill, birçok konuda Stalin ile görüş ayrılığı yaşamıştır. Konferansın ardından müttefikler arasında rekabet dönemi başladı çünkü müttefikler arasındaki bu farklı tutum ve davranışlar savaş sırasında kurulan ittifakın zedelenmesine ve güvensizliğe neden oldu.

Savaş sırasında, İngiltere ve ABD Sovyetler Birliği'nin askeri gücüne ihtiyaç duyuyorlardı; yani onları birleştiren tek şey, Almanya'ya karşı olan nefretleriydi. Ortada nefret duyulan ve savaşılan bir düşman kalmadığı için savaş sırasındaki müttefiklik durumu artık bozuluyordu. Dünya Savaşı resmen sona erdiğinde, bir zamanlar ortak bir düşmana karşı savaşan müttefikler artık birbirlerini 'tartma' vakti buldu. Lenin'in öngördüğü 'komünizm' idealini çarpıtan Stalin'in Sovyetleri Orta ve Doğu Avrupa'da etki alanlarını genişletmeye ve komünizmi yaymaya başladılar. Buna karşılık olarak Batılı ülkeler ve özellikle Amerikalılar, Komünizmi engellemeye dönük politikalar uyguluyorlardı. Yani, iki taraf da güçlerini ve yaşam biçimlerini korumak için doğru olduğuna inandıkları şeyleri yapıyorlardı.

${ }^{16}$ Clare, J. D. (2017).Personalities At TheConferences.

http://www.johndclare.net/cold_war4_personalities.htm. Erişim Tarihi: 30.05.2017 
Altı yıl süren kanlı savaşın çıkış noktası olan Almanya, Yalta Konferansında alınan dört devlet arasında 'bölünme' kararıyla aslında Sovyetler ve Batılı Güçler arasında yeni bir çatışmanın da tohumlarını atmıştır. Almanya'nın parçalanması sadece aileleri parçalamakla kalmamış Doğu ile Batıyı da birbirinden ayırmıştır. Müttefikler arasında savaşın sonlarına doğru ortaya çıkan 'güvensizlik' duygusu Yalta'dan sonra somut hale dönüşmüş ve Almanya ve Doğu Avrupa üzerinden yayılmaya başlayan bir bloklaşma oluşmuştur. Yalta'dan sonra önemli liderlik değişimleri de yaşanmıştır. Amerika'da Başkan Roosevelt ölmüş yerine kendisine göre daha sert ve kararlı birisi olan yardımcısı Harry Truman gelmiştir; İngiltere'de ise Churchill seçimlerde Başbakanlığı Atlee'ye kaybetmiştir. SSCB'de ise herhangi bir yönetim değişikliği yaşanmamıştır.

Yalta'da tohumları atılan müttefikler arası güvensizlik birkaç ay sonra Potsdam Konferansında su yüzüne çıkmış; Amerikan Başkanı Truman'ın Japonya'yı teslim almak için atom bombası kullanımına onay vermesi de aslında ABD’nin Pasifikte Staline'e ihtiyacı kalmadığını ve ayrıca Sovyetler'e bir gözdağı ve güç gösterisi olarak algılanabilir çünkü atom bombasına sahip olma, ABD’yi dünyada tek süper güç kılıyordu. Bunun için Sovyetler bir an evvel atom bombasının yapımını gizlice ele geçirmek istiyorlard1. 1947'de Sovyetlerin Berlin'i kuşatması ve Batılı güçlerin Berlin'le bağlantılarını koparması ve daha sonra SSCB'nin bir şekilde atom bombası yapımını öğrenmesi güçler arasındaki ayrımı iyice belirginleştirmiş ve dünyanın 1990’ların başına kadar sürecek bir çift kutuplu Soğuk Savaş dönemi yaşamasına yol açmıştır. 


\section{Kaynakça}

Clare, J. D. (2017). Personalities At The Conferences. http://www.johndclare.net/cold_war4_personalities.htm. Erişim Tarihi: 30.05 .2017

Clare, J. D. (2017). Personalities At The Conferences. http://www.johndclare.net/cold_war4_personalities.htm. Erişim Tarihi: 30.05.2017

Clare, J. D. (2017). Personalities At The Conferences. http://www.johndclare.net/cold_war4_personalities.htm. Erişim Tarihi: 30.05.2017

ctdt.blogcu.com, 2017. Soğuk Savaşa Geçiş Dönemi 1945-

1947.http://ctdt.blogcu.com/soguk-savasa-gecis-donemi-1945-1947/4294208. Erişim Tarihi: 30.05.2017

ctdt.blogcu.com, 2017. Soğuk Savaşa Geçiş Dönemi 1945-1947. http://ctdt.blogcu.com/soguk-savasa-gecis-donemi-1945-1947/4294208. Erişim Tarihi: 30.05 .2017

Engbith, L. (2011).True Diplomacy At Yalta. http://www.ctn.state.ct.us/press_room/osh/NHDYalta.pdf. Erişim tarihi: 25.04.2017

Forrest C. Pogue, C. F. (1956). The Meaning of Yalta. Louisiana: Louisiana State Press.

Forrest C. Pogue, C. F. (1956). The Meaning of Yalta: Big Three Diplomacy and New Balance of Power. Louisiana: Louisiana State University Press.

history.state.gov, (2017).The Yalta Conference, 1945. https://history.state.gov/milestones/1937-1945/yalta-conf. Erişim Tarihi: 01.06.2017

Kemal Yakut, E. Y. (2013). Siyasi Tarih-II. Eskişehir: Anadolu Üniversitesi Yayınlar1.

Sander, O. (1989). Siyasi Tarih. Ankara: İmge Kitabevi Yayınları.

Scott, N. (2017). The Conferences At Yalta and Potsdam. http://www2.needham.k12.ma.us/nhs/cur/Baker_00/2002-p3/baker_p3_1201 sn/. Erișim Tarihi: 31.05.2017

www.cvce.eu, (2017). The Cold War 1945-1989. www.cvce.eu/obj/the_cold_war_1945_1989_full_text-en-6dfe06ed-479048a4-8968-855e90593185.html.Erişim Tarihi: 29.05.2017 
www.thelatinlibrary.com, (2017). The Yalta Conference, 1945.

http://www.thelatinlibrary.com/imperialism/notes/yalta.html. Erişim Tarihi: 02.06.2017

www.thelatinlibrary.com, (2017). The Yalta Conference, 1945.

http://www.thelatinlibrary.com/imperialism/notes/yalta.html. Erişim Tarihi: 02.06.2017 